\title{
An overview of international institutional mechanisms for environmental management with reference to Arctic pollution
}

\author{
Patricia E. Perkins \\ Faculty of Environmental Studies, 355 Lumbers Building, York University, North York, Ontario M3J 1P3, Canada
}

\begin{abstract}
Evidence is mounting of the environmental impact in the Far North of economic and industrial activity elsewhere in the world. While the sources of pollutants found in the Arctic are many and widespread, it is up to just a few countries - notably Canada, the former Soviet Union, Finland, Norway and Greenland - to assess the damage and deal with the impacts. This papcr discusses the issue of Arctic pollution in the context of trends in world economic growth, globalization of economic activity, international trade and related institutional arrangements (such as trade and environmental agreements). The importance of tracing the sources of particular contaminants is stressed; this is a first step towards internalization of environmental costs of production, and is also politically a key in efforts to control emissions. Trade and investment agreements commonly discuss rules for cross-border flows of goods, services, personnel and investment capital, as well as matters specific to particular economic sectors. Cross-border flows of pollutants and other 'bads' also merit detailed sectoral attention. This linkage would make explicit the connections between production and pollution (making possible the 'polluter pays' approach), and also widen the scope for redistribution of economic resources to equilibrate the situation (via trade and investment measures, among others) if flows of goods are related directly to flows of 'bads'. The paper examines the outlook for addressing Arctic pollution via international environmental agreements (along the lines of the Basel Convention, the Montreal Protocol, CITES, etc.), existing and future trade agreements (such as GATT), or new institutional approaches.
\end{abstract}

Keywords: International environmental agreements; Trade and environment; Arctic pollution control

\section{Introduction}

The signing of the Nuuk Declaration on Environment and Development in the Arctic marked a significant link in the chain of agreements aimed at protecting the Arctic environment. Earlier links include the Rovaniemi conference of Arctic rim states in 1989, the June 1991 signing of the Declaration on the Protection of the Arctic Environment, adoption of the Arctic Environmental Protection Strategy, and establishment of the Arctic Monitoring and Assessment Program, also in 1991 (Soroos, 1993). 
Meeting at Nuuk, Greenland, in September 1993, representatives of the Ministers of the Environment of the eight circumpolar nations agreed to 'cooperate, protect, and, as appropriate, restore the ecosystems of the Arctic'. They pledged to seek resources to do this, reaffirmed their commitment to implementing the Arctic Environmental Protection Strategy, and agreed to establish a working group on further policy actions required (Nuuk Declaration, 1993).

Growing evidence on the degree and spread of arctic pollution makes it clear that ongoing international measures to halt the continued contamination of the arctic environment are extremely important. This paper briefly surveys the history of international attempts to deal with other large-scale environmental problems, categorizing the various approaches that have been attempted and discussing their applicability in the case of arctic pollution. It also explores the opportunities offered by trade measures to strengthen compliance with such international environmental pacts.

At the outset, it must be pointed out that, although environmental problems tend to be closely related to natural processes (wind and ocean currents, riverine drainage basins, animal migrations, groundwater flows, etc.), the political measures humans adopt to address these problems are almost always geographically limited by political boundaries. Until the day, perhaps not so very far in the future, when political governance is determined by ecology, this means that any sort of international pollution control mechanism is inevitably problematic. In order to obtain cooperation from all the political jurisdictions that may be contributing to the environmental problem, the support of many constituents who are unaffected by and uninterested in the problem may be necessary.

As existing and proposed international environmental agreements demonstrate, the process of reaching consensus on the need for and terms of such accords is fraught with difficulties (Macdonald, 1991). Moreover, even where they have been approved, compliance and enforcement are often spotty (U.S. GAO, 1992a).

In the absence of a global body with the authority, budget, and clout to enforce international environmental agreements, nations have been forced to fall back on traditional political mechanisms, dealing with environmental matters along with other international disputes (Boardman, 1992). Indeed, some would argue that this is as it should be. Greve and Smith, for example, emphasize the crass political nature of environmental policy making in general, and cite the case of the Montreal Protocol on ozone-depleting substances as one in which the process of international agreement was influenced by and worked in favor of corporate interests (Benedick, 1991; McInnis, 1992; Greve and Smith, 1992).

From this viewpoint, a broad decision making process for international environmental issues, which would allow them to be mediated politically through the intervention of many different actors, might seem preferable to a more limited decision making process in which a few moneyed interests can hold sway. Greve and Smith advocate 'reforms that stimulate and institutionalize the competing and conflicting considerations that should inform the management of environmental risk' (p. 185, Greve and Smith, 1992). This idea implies that creating special international agreements to address environmental issues may not be the most advisable way of addressing these problems; why make exceptions to the multistakeholder processes established through existing national, diplomatic, and international policy channels?

However, the pressing nature of some international environmental problems, and the inefficacy of most traditional political processes in dealing with them, have led to hundreds of international accords on environmental matters. This seems to be the manner of choice for addressing international or global environmental concerns (Stevis et al., 1992). About two dozen of these international environmental agreements contain provisions allowing the use of trade measures to encourage participation or enforce compliance (GATT, 1991; Runnals and Cosbey, 1992; Walker, 1993).

Trade agreements themselves may be able to play a large role in international environmental issues, since trade sanctions (or the threat thereof) offer an important lever for bringing about international compliance. Some environmentalists see 
hopeful signs in the impetus toward 'greening' a post-Uruguay Round of the General Agreement on Tariffs and Trade (GATT) and in the emphasis on environmental issues and dispute settlement mechanisms in the North American Free Trade Agreement and its environmental side deal (National Wildlife Foundation, 1991; Pollution Probe, 1992).

A more cynical view draws upon evidence concerning the growing globalization of the world economy and the concomitant weakening of national governments' power vis-a-vis transnational corporations (Gordon, 1993) to draw stark conclusions concerning the ability of national governments to deal adequately with international pollution. In this analysis, even national environmental regulations are progressively undermined by transnational firms' ease in shifting their operations to areas with laxer rules; trade agreements that facilitate international transfers of capital and technology (but not labor) only accentuate the trend (Campbell, 1993).

In the sections that follow, each of these perspectives is more fully explored and discussed in relation to arctic pollution. The concluding section hazards some preliminary remarks about the international political economy of achieving consensus on mechanisms to address arctic pollution, and discusses the role of scientific research in achieving the levels of diplomatic commitment needed.

\section{International environmental agreements}

Most previous international environmental agreements have dealt mainly with stopping current and future emissions or worsening of the problem, not with remediating the effects of past contamination. Although it is tempting to want to address all aspects of arctic contamination with one policy instrument, this could inject a number of complications. High clean-up costs could raise internal political difficulties for an international agreement in the countries asked to help pay these costs, fracturing domestic support for the accord in signing countries.

Unlike reductions in future benefits, which can be compensated for via technology and invest- ment shifts, or costs that fall in the future, which can be paid for out of future operating profits, lump-sum costs for clean-ups represent a significant drain in financial terms with little possibility of easing the burden. Unless these costs are to be paid directly by governments, with resulting damage to the international agreement's support on the part of the general taxpaying public, they have the potential to be very damaging to the internal political consensus about the agreement.

Disagreements regarding the international sharing of costs and benefits could also be heightened if remediation of existing contamination were to be included in the discussion. Raising the stakes in money terms might well increase the level of conflict, and mixing clean-up costs with the redistribution of benefits from expected pollution reductions in the future could greatly complicate the international negotiations.

Parties concerned may well decide that one over-arching policy approach is needed to address both past and present/future issues related to arctic contamination, despite the points raised in the preceding paragraphs. This discussion serves to emphasize, however, that it is possible to delink present/future problems from past ones in proposing international solutions, and that different countries may have different roles to play in each of the two matters.

The question of international leadership will depend in part on the forums chosen as venucs for discussions of the arctic pollution question. The United Nations Environment Programme is poised to assume leadership in issues of this sort (Kimball, 1992); trade bodies such as GATT may also have a role to play, as discussed in the sections that follow; and the level of commitment of the countries directly involved may be sufficient to reach a regional accord on the issue.

It should be noted that signing an international environmental agreement would not be enough to ensure that the problem would go away; monitoring and enforcement mechanisms are key to the long-term success of any accords that may be struck (U.S. GAO, 1992b). As discussed later, this implies an ongoing institutional commitment and structure for cnsuring that agrcements arc complied with to attain pollution reductions, which 
ideally should be part of the original international agreement.

\section{Trade agreements}

Until very recently, about one-quarter of world trade took place under bilateral country-to-country agreements, another quarter was barter (mainly between state trading firms of Warsaw Pact nations), a quarter was 'intrafirm trade' between subsidiaries of the same corporation in various countries, and only the remaining quarter involved multilateral trade of goods and services on the international market (Schmidheiny, 1992). The international trading system is currently in a state of flux, due to the many economic changes taking place in castern Europe and the former Soviet Union.

The potential impacts of trade agreements on arctic pollution are diametrically opposed: they could contribute to the problem, and/or to its solution. Because of the growing importance of trade in the world economy, and especially the large potential increases in multilateral trade between the West and the former Soviet Union, we examine each of these considerations in some detail.

\subsection{Trade agreements as a problem}

Because trade alters the international flows and volume of production and consumption, it clearly affects the environment in a number of ways. If adequate environmental controls are not in place, or are slow to be implemented as trade patterns shift, accelerated resource depletion and pollution may result.

The environmental policies of one country may also affect others via trade, because all taxes, subsidies, and regulations affect international competitiveness. A country's own environmental regulations may be undercut by cheap imports produced in countries with less stringent environmental policies, and import restrictions may be called for in response. (It is unlikely that such restrictions could be defended under the current GATT or NAFTA.) Industries seeking protection from foreign competition may, however, claim environmental concerns when their principal mo- tive is less altruistic, for example, in calling for a tariff against foreign paper, ostensibly because of the unsustainable logging practices used in its producing country.

The principal international organization that regulates multilateral trade is GATT - the General Agreement on Tariffs and Trade (GATT). When GATT was sct up 35 years ago, environmental issues were less well understood and seemed less important than at present. In its 'General Exceptions' provision (Article XX), GATT allows member countries to act to protect 'human, animal or plant life or health' and to take 'measures relating to the conservation of exhaustible natural resources if such measures are made effective in conjunction with restrictions on domestic production and consumption', (General Agreement on Tariffs and Trade, Article XX (b) and Article XX (g)), as long as these steps do not constitute a disguised restriction on international trade (GATT, 1986).

Much of the current debate concerning GATT's environmental impact centers on whether these two provisions afford enough protection to permit legitimate environmental policies. Trade dispute precedents indicating how GATT panels are likely to interpret these provisions are inconclusive (or, some environmentalists charge, ominous; Walker, 1993).

Actually, few GATT disputes have arisen in which an environmental measure has been challenged. The most relevant and controversial was the tuna-dolphin case. A GATT dispute resolution panel ruled in September 1991 that it was a violation of GATT for the U.S. to ban imports of yellowfin tuna from Mexico and several other Latin American countries because of the fishing practices allowed there (but not in the U.S.), which kill dolphins accidentally caught in purseseine fishing nets. The GATT panel ruled that no GATT member country may restrict trade for the purpose of protecting the environment beyond its own borders (Inside U.S. Trade, 1991).

A number of international conventions and protocols dealing with environmental protection and conservation may, under this interpretation, violate the GATT - such as the 1987 Montreal Protocol on ozone-depleting substances, the 1989 
Basel Convention on transport of hazardous wastes, and the 1973 Convention on International Trade in Endangered Species (CITES) of Wild Fauna and Flora. More than 150 existing international treaties and other agreements have environmental implications (GATT, 1991); about 20 of these specifically mention the possibility of using trade sanctions for enforcement or involve trade in other ways (GATT, 1992). It should be noted that a 1992 GATT report puts forward the argument that any environmental policies that are broadly supported in the world community would not be blocked by GATT rules, because these can be changed or waived by two-thirds of the GATT member countries (pp. 5-6, GATT, 1992). This raises the clear possibility that an international consensus on important environmental issues - though admittedly difficult to achieve - could override trade considerations and lead to permanent modifications of the GATT.

Although no country has as yet challenged an international environmental agreement on trade grounds, it is possible that a country that was discriminated against might be able to win a GATT ruling and adopt retaliatory trade measures, with GATT's approval. To avoid undercutting international agreements intended to address pressing global environmental problems, it is important that the order of precedence between such agreements and GATT be clarified (Sorsa, 1992).

In addition to GATT's problematic stance on international environmental agreements, various authors have described several broad groups of potential problems with traditional GATT-type trade-agreements, from an environmental point of view. These include problems relating to standards, to subsidies and other economic instruments, to investment and growth, to the permissible uses of trade measures, and to institutional changes and national governance (Ritchie, 1990; Shrybman, 1990; Arden-Clarke, 1991; Daly, 1992; Canadian Environmental Law Association, 1993). For many environmentalists and others, trade liberalization along GATT-managed lines skews economic growth in an environmentally negative direction.

\subsection{Trade agreements as a solution}

Along with or despite the impacts noted in the previous section, and depending on many other circumstances, trade may lead to welfare and income increases that make environmental improvements financially possible and increase people's interest in them (GATT, 1992; Anderson and Blackhurst, 1992). Moreover, if GATT reforms clarify the issue, trade measures could become an effective way of encouraging international participation and compliance with environmental agreements such as the Montreal Protocol.

Several authors argue that using trade sanctions to enforce environmental agreements is a third-best solution, since trade itself is not the prime cause of the environmental problems; domestic national policies aimed directly at the issue are more efficient in bringing about the desired environmental improvements (Baumol, 1971; Barbier et al., 1990; Sorsa, 1992). Sorsa gives five arguments for why unilateral trade sanctions should not be used to deal with international environmental problems: (1) scientific evidence regarding many such problems is uncertain or subject to value judgments, (2) the source of pollution and the underlying causal relationship is often hard to establish, (3) polluters can always direct exports to other countries if sanctions are employed, (4) effects-based trade rules would be hard to devise, and (5) the effectiveness of sanctions would be related to the size of the country imposing them. Instead of trade sanctions, Sorsa says, countries should use moral suasion, product labelling, awareness building, and financial or technological transfers to address cross-border environmental problems (Sorsa, 1992).

A response to the above arguments lies in the scale and importance of the international environmental issues being addressed, and the lack of alternate means of obtaining international compliance and participation. Environmental legislation at the national level has, in many cases, effectively transformed local pollution problems into international ones, as technologies based on control of emissions concentrations have simply allowed emissions to be diluted and spread farther afield (Diwan and Shafik, 1992). 
In Sudbury, Ontario, for example, a 'superstack' constructed in the early 1970 s on a large nickel smelter injected its emissions into the upper atmosphere; instead of reducing pollution at the source, the stack simply spread the emissions more widely. As long as environmental regulation techniques and market incentive structures foster this trend, a viable counterbalance is imperative.

Nations have relatively few options, short of war, for influencing their neighbors' environmental policies. Pollution control instruments commonly used within countries - such as tax policies, regulations, and tradeable emissions permits - are usually not applicable on the international level, due to the lack of institutional structures for implementing and enforcing them. Trade action, although admittedly a very blunt instrument, deserves serious attention.

Although GATT rules seek to reduce government-imposed barriers to trade in goods and services, it is becoming clearer that they also facilitate cross-border transfers of 'bads': pollution, lax standards, poor enforcement, and over-exploitation of resources. The argument that these are difficult to measure, trace, and understand, and subject to value judgements, speaks only to the need for more attention to these matters, both by empirical researchers and in the court of public opinion. Because environmental risk and harm is borne by the public in general, it is understandable that public interest and concern in trade-related matters is growing.

GATT panels have decades of experience in determining whether trade injury to some nations has resulted from others' dumping practices, subsidies, and price intervention in markets for traded goods. In routine trade disputes, an estimate is made of the amount of injury that has occurred and of the countervailing duty that will fairly compensate for others' unfair trade practices. Although it is certainly difficult to place a dollar value on environmental damage, the argument that similar procedures cannot be constructed for measuring and compensating environmental injury is lazy at best.

Moreover, trade agreements could be modified in entirely new ways to reflect their importance in and responsibility for addressing international en- vironmental problems. Consider this possible scenario: countries would be able to impose an across-the-board duty on all goods and services imported from other nations that are the source of cross-border pollution or other environmental 'bads'. The total value of the duty would be equal to the value of the harm or damage suffered by the importing country. This determination would be made by an international panel composed of environmental scientists, economists, and other specialists, who would hear evidence presented by both the importing country and the exporting country before setting the permissible duty. The effect would be to incorporate true environmental costs into market prices in the importing/consuming country. Revenues raised from the duty would accrue to a fund earmarked for environmental remediation and pollution prevention, preferably one administered internationally.

Because the duty would be levied on all goods and services imported from the offending country, the exporting nation would be free to enact domestic policies in whatever way it chose to address the problem. This would allow a degree of equity and choice for the offending country, although, depending on the policies chosen, it could remove direct sectoral incentives for making the polluter pay. But the most significant effect of an across-the-board pollution duty would be to remove the incentive to use environmental arguments as a cover for protectionist trade policies, which is probably the single thorniest issue in the debate on trade and environment questions. Trade sanctions of this sort would not be subject to the sort of retaliatory harassment that has characterized most past sectoral disputes involving environmental claims. Existence of such a fund to pay up-front pollution costs would ease political acceptance of the idea that pollution control is a top priority issue, and would also supplement other available sources of funds for pollution reduction and remediation.

In order to regain its former market access to the importing country, after redressing the crossborder pollution issue, the offending country could reconvene the environmental panel to hear its new evidence on the level of cross-border flows. The importing country could again present 
its own evidence as well. On particularly contentious issues, there might be a need for continuous monitoring systems, which could be established and financed jointly by both countries and overseen by the international environmental panel.

Could such a scheme work? It would depend on the level of trade between the countries involved, and on the desire of both to keep trade flows as efficient as possible. Would it be permissible as GATT now stands? Probably not. Does it make sanctions imposed on environmental grounds more accessible to those with the most market power? Probably. But this is true of existing trade rules also; and at present there is almost no scope for using trade agreements for environmental ends.

Such an institutional arrangement would represent an admission by the international community that, in some cases, trade liberalization is not the world's primary goal. Perhaps it is premature to expect such an admission. The issue of arctic contamination offers a key opportunity to question old assumptions and to explore new approaches to the reduction of long-range pollution flows. Environmental objectives, far from being subordinate to trade-related ones, are crucial to ensure the long-term viability of economies whose development trade is itself aimed at enhancing.

\section{Globalization and environmental controls}

If some theorists are correct, the growth of world trade under the aegis of trade agreements such as GATT serves principally to enhance the power of transnational corporations vis-a-vis national governments; the ability of countries to shape their own economies and enact environmental controls is already on the wane (Campbell, 1993; Drache, 1993). The evidence of these trends is strong, and if the political will to address issues such as arctic pollution is elusive, this factor should serve as an additional incentive.

International initiatives such as the Brundtland Commission, the United Nations Conference on Environment and Development (UNCED) in Rio de Janeiro, creation of the Global Environment
Facility (GEF), and the proposed 'Green Round' of the GATT all demonstrate the world's growing acceptance that economic and environment questions cannot be viewed in isolation from each other (Trade News Bulletin, 1992). The postWorld War II preoccupation with stimulating world economic development by abolishing protectionism, which spawned GATT, is giving way to recognition that social and economic principles are at least as important as free trade for its own sake.

There is clearly a need for ongoing international discussions - in a broader forum than the Organization for Economic Cooperation and Development, or even the GATT - to address the sustainability of trade and trade's contribution to overall economic sustainability in the context of global environmental issues. The United Nations Environment Programme and UNCTAD would be obvious choices to take the lead in forming such a new body (Kimball, 1992).

This forum would provide a context for ongoing discussion of world issues such as arctic pollution, along with global warming, ozone depletion, climate change, redistribution of economic resources for environmental purposes, deforestation, and many others. These issues have many ramifications for international trade, and trade implications should be incorporated into the environmental discussion, along with ways in which trade policy can further environmental ends. This proposal sets current practice on its head, but it represents a rational long-term approach to trade and environment questions.

\section{Requisites for international cooperation on Arctic pollution}

What would be required to bring about this shift in emphasis, in order to address arctic pollution at an institutional level? Several factors could contribute:

- Mounting and widely accepted scientific evidence of the scale, effects, causes, and interlinkages of cross-border pollution transfers to the Arctic and their specific origins. 
- A groundswell of international public opinion calling for attention to the issue and a halt to continued arctic contamination.

- Recognition by world leaders and by leaders in the most affected and most responsible countries that arctic pollution is a key political issue.

- Willingness on the part of others who are affected less centrally to countenance innovative new approaches to resolving the arctic contamination issue, including approaches with implications for long-established institutions such as the GATT.

Cleariy, these steps are all interconnected. The scientific community has a large and vital role to play in accomplishing this transformation; as in the case of most environmental issues, public information and education leading to political commitment is the key to change. How far-reaching and effective this change can be is, in large part, up to those of us who are responsible for researching the issue and teaching others about the threat arctic pollution represents for the global environment.

\section{References}

Anderson, K. and R. Blackhurst (Eds.), 1992. The Greening of World Trade Issues. Harvester Wheatsheaf, London.

Arden-Clarke, C., 1991. The General Agreement on Tariffs and Trade: Environmental Protection and Sustainable Development. World Wildlife Fund International, Gland, Switzerland.

Barbier, E.B., J. Burgess, T. Swanson and D.W. Pearce, 1990. Elephants, Economics and Ivory. Earthscan, London.

Baumol, W.J., 1971. Environmental Protection, International Spillovers and Trade. Almqvist and Wixell, Stockholm.

Benedick, R.E., 1991. Ozone Diplomacy. Harvard University Press, Cambridge, MA.

Boardman, R., 1992. The multilateral dimension: Canada in the international system. In: R. Boardman (Ed.), Canadian Environmental Policy: Ecosystems, Policy and Process. Oxford University Press, London.

Campbell, B., 1993. Globalization, trade agreements and sustainability. In: Canadian Environmental Law Association, The Environmental Implications of Trade Agreements. Report prepared for the Ontario Ministry of Environment and Energy, Queen's Printer for Ontario, Toronto.

Canadian Environmental Law Association, 1993. The Environmental Implications of Trade Agreements. Prepared for the Ontario Ministry of Environment and Energy, Queen's Printer for Ontario, Toronto.

Daly, H.E., 1992. Problems with free trade: neoclassical and steady-state perspective. In: D. Zaelke et al. (Eds.), Trade and the Environment. Island Press, Washington.

Diwan, I. and N. Shafik, 1992. Investment, technology and the global environment: towards international agreement in a world of disparities. In: P. Low (Ed.), International Trade and the Environment. The World Bank, Washington.

Drache, D., 1993. The Sovereignty of Nations in a Corporate Age From Keynes to K-Mart. Mimeo.

GATT, 1986. General Agreement on Tariffs and Trade, Agreement on Technical Barriers to Trade, Preamble, The Texts of the Tokyo Round Agreements. General Agreement on Tariffs and Trade (GATT), August 1986, Geneva.

GATT, 1991. Trade and Environment: Factual Note by the Secretariat. General Agreement on Tariffs and Trade (GATT), September 1991, Geneva, Annex III.

GATT, 1992. Trade and the Environment, part of the annual report entitled International Trade 1990-1991. General Agreement on Tariffs and Trade (GATT), March 1992, Geneva.

Gordon, D.M., 1993. The Global Economy: New Edifice or Crumbling Foundations? ILO Review, Summer 1993.

Greve, M.S. and F.L. Smith, Jr., 1992. Environmental Politics: Public Costs, Private Rewards. Praeger, New York.

Inside U.S. Trade, 1991. Findings of GATT Dispute Panel on U.S. Tuna Ban. Inside U.S. Trade, 6 September 1991.

Kimball, L., 1992. Forging International Agreement: Strengthening Intergovernmental Institutions for Environment and Development. World Resources Institute Report, United Nations Environment Programme.

Macdonald, D., 1991. The Politics of Pollution. McClelland and Stewart, Toronto.

McInnis, D.F., 1992. Ozone layers and monopoly profits. In: M.S. Greve and F.L. Smith, Jr. (Eds), Environmental Politics: Public Costs, Private Rewards. Praeger, New York.

National Wildlife Foundation, 1991. Memo from President Jay D. Hair to U.S. Trade Representative Carla Hills, 20 November 1991.

Nuuk Declaration on Environment and Development in the Arctic, 1993. In: The Arctic Environment: Second Ministerial Conference, 16 September 1993, Nuuk, Greenland. Ministry of Foreign Affairs, Copenhagen.

Pollution Probe, 1992. Canadian Trade Negotiators Should Finish the Job of Incorporating Environmental Safeguards in NAFTA. Toronto.

Ritchie, M., 1990. GATT, agriculture and the environment: the U.S. Double Zero Plan. Ecologist, 20: 214-220.

Runnalls, D. and A. Cosbey, 1992. Trade and Sustainable Development: A Survey of the Issues and a New Research Agenda. International Institute for Sustainable Development, Winnipeg.

Schmidheiny, S., with the Business Council for Sustainable Development. 1992. Changing Course: A Global Business Perspective on Development and the Environment. MIT Press, Cambridge, MA. 
Shrybman, S., 1990. International trade and the environment: an environmental assessment of the GATT. Ecologist, 20: 30-34.

Soroos, M.S., 1993. Arctic haze and transboundary air pollution: conditions governing success and failure. In: O.R. Young and G. Osherenko (Eds.), Polar Politics: Creating International Environmental Regimes. Cornell University Press, Ithaca, NY.

Sorsa, P., 1992. GATT and the environment: basic issues and some developing country concerns. In: P. Low (Ed.), International Trade and the Environment. The World Bank, Washington.

Stevis, D., V.J. Assetto and S.P. Mumme, 1992. International environmental politics: a theoretical review of the litera- ture. In: J.P. Lester (Ed.), Environment, Politics and Policy: Theory and Evidence. Duke University Press, Durham, NC. Trade News Bulletin, 1992. Dunkel Says GATT Must Protect Environment. Trade News Bulletin, 11 August 1992.

U.S. GAO, 1992a. International Environmental Agreements are Not Well Monitored. U.S. General Accounting Office, January 1992, Washington, DC.

U.S. GAO, 1992b. Strengthening the Implementation of Environmental Agreements. U.S. General Accounting Office, August 1992, Washington, DC.

Walker, S.L., 1993. Regulating International Trade and the Environment: Finding the Balance. Publications des facultes universitaires, Saint-Louis, Brussels, Belgium. 